DOI: https://doi.org/10.24867/09MO01Dorotka

\title{
ANALIZA RADA POSTROJENJA ZA PREČIŠĆAVANJE OTPADNIH VODA U NASELJU KOVILJ
}

\author{
OPERATION ANALYSIS OF WASTEWATER TREATMENT PLANT
}

\author{
Asja Dorotka, Maja Turk Sekulić, Radoica Stefanović, Branka Vučković, Fakultet Tehničkih \\ Nauka, Novi Sad, Javno komunalno preduzeće Vodovod i kanalizacija, Novi Sad
}

\section{Oblast - INŽENJERSTVO TRETMANA I ZAŠTITE VODA-TEMPUS}

Kratak sadržaj - U radu je predstavljen $i$ analizan projekat izgradnje postrojenja za prečišćavanje otpadnih voda opštine Kovilj sa hidrauličkim proračunima za dimenzioniranje tretmana procesa sekvencijalno-šaržnog reaktora, proces kontrole kvaliteta generisanog mulja $i$ otpadne vode. Na osnovu rezultata parametara kvaliteta izlaznih efluenata ocenjen je stepen efikasnosti rada postrojenja.

Ključne reči: Otpadna voda, Procesi prečišćavanja otpadnih voda, Biološki proces prečišćavanja, SBR reactor, Parametri, analize $i$ kvaliteta otpadnih voda, Mulj, Stabilizacija mulja

\begin{abstract}
The paper presents and analyzes the project of wastewater treatment plantconstruction in Kovilj municipality with hydraulic calculations for sizing the treatment of the sequential-batch reactor process, the process of quality control of the generated sludge and wastewater. Based on the quality parameters results of the output effluents, the degree of plant efficiency was estimated.
\end{abstract}

Keywords: Wastewater, Wastewater treatment processes, Biological treatment process, SBR reactor, Quality of wastewater, Sludge, Sludge stabilization

\section{UVOD}

Zadatak prečišćavanja otpadnih voda je eliminisanje ili smanjenje, u određenom procentu, zagađujućih materija u njima. Najznačajnije karakteristike otpadne vode su organsko opterećenje (BPK $\mathbf{5}, \mathbf{H P K})$, količina suspendovanih materija (SS), nutrijenti azot i fosfor, temperatura, miris, teški metali, mutnoća, boja, patogeni organizmi i $\mathrm{pH}$ vrednost. Redukcija rastvorene i dispergovane biorazgradive organske materije, azota $(\mathrm{N})$, fosfora $(\mathrm{P})$ i stabilizacija organske materije postiže se putem različitih mikroorganizama, prvenstveno bakterija. Zakonskim uredbama su definisani i propisani uslovi u pogledu kvaliteta efluenta (prečišćena otpadna voda) za ispuštanje $\mathrm{u}$ recipijent koji služe prilikom dizajniranja tretmana za određivanje potrebnog stepena prečišćavanja otpadne vode.

\section{NAPOMENA:}

Ovaj rad proistekao je iz master rada čiji mentor je bila dr Maja Turk Sekulić, van. prof.
Veličina postrojenja zavisi od broja stanovnika, njihovog načina života, geografskog područja, veličine slivne površine, razvijenosti industrije, količine i sastava otpadnih voda [1].

Izbor efikasnog i izvodljivog procesa zavisi od kvaliteta ulazne otpadne vode, kvaliteta izlazne prečišćene otpadne vode, prostora potrebnog za postrojenje, nusproizvoda i kvaliteta emisija [2].

\section{OPIS SBR PROCESA PREČIŠĆAVANJA OTPADNIH VODA NA POSTROJENJU}

Projektno rešenje postrojenja za prečišćavanje otpadnih voda u naselju Kovilj obuhvata mehanički tretman, biološki tretman, i tretman mulja koji nastaje u toku prerade vode. Mehaničko prečišćavanje obuhvata odvajanje krupnih nečistoća, inertnog materijala, peska, masti i ulja na gruboj i finoj rešetci. Pesak i masnoća se uklanjaju u aerisanom peskolovu sa hvatačem masti.

Otpadna voda iz peskolova se gravitaciono odvodi $\mathrm{u}$ razdelnu građevinu gde se preko oštroivičnog preliva tok deli na dva jednaka dela i odvodi dalje na biološko prečišćavanje u sekvencijalno-šaržni (SBR) reaktor. SBR je proces sa kontinualnim dotokom vode kojim se uklanjanju ugljenično organsko zagađenje i nitrifikuju azotna jedinjenja.

Obuhvata simultane procese nitrifikacije i denitrifikacije. Specifični mikroorganizmi (Nitrosomonas i Nitrobacter) imaju sposobnost da oksidišu amonijak do nitrita i nitrata $\mathrm{u}$ procesu oksidacije, dok druge bakterije mogu da prevedu oksidovani azot $\mathrm{u}$ gasoviti azot $\mathrm{u}$ procesu denitrifikacije (proces bez $\mathrm{O}_{2}$ ) [3].

Denitrifikacija je anaerobni proces u kojem se troši nitrat kao zamena za $\mathrm{O}_{2} \mathrm{i}$ uklanja $\mathrm{BPK}_{5}$. Nitrati su posledica organske kontaminacije vode, nastaju aerobnom mikrobiološkom razgradnjom belančevina i drugih organskih sastojaka sa azotom.

Faze obuhvaćene SBR procesom su: faza reakcije (aerisanja), faza taloženja (sleganje smeše vode i aktivnog mulja na dno bazena) i faza ceđenja (dekantovanje). Tokom biološkog procesa nastaje mulj čije se prečišćavanje (uklanjanje patogenih mikroorganizama) i stabilizacija odvija procesima obrade mulja u zavisnosti od njegovog kvaliteta i količine.

Organske materije i teški metali čine mulj nestabilnim i izazivaju razvoj bakterija. Prednosti SBR sistema su što nema potrebe za povratnim aktivnim muljem, fleksibilne operacije čime se može uticati na efikasnost uklanjanja 
nutrijenata $\mathrm{i}$ to što se biološki tretman i sekundarno taloženje odvijaju u okviru jednog reaktora (aeracioni bazen). Količina kiseonika potrebna za proces aeracije se $\mathrm{u}$ reaktor unosi duvaljkama u vidu finih mehurova. Odvod prečišćene vode se vrši dekanterima.

Proračunom je utvrđeno da je jedan dekanter u jednom reaktoru dovoljan da svojim kapacitetom obezbedi odvod tretirane otpadne vode.

Cilj obrade mulja jeste smanjenje sadržaja vlage u njemu. S obzirom da starost mulja iz SBR bazena nije dovoljna za odlaganje mulja na uređenu gradsku deponiju, vrši se dopunska stabilizacija mulja u aerobnom digestoru. Smanjenje zapremine mulja (zgušnjavanje mulja) se postiže povremenim zaustavljanjem procesa aeracije $u$ aerobnom digestoru. Stabilizovan mulj se iz aerobnog digestora vijačnom pumpom potiskuje na mašinsko odvodnjavanje centrifugom.

\section{OPIS HIDRAULIČKOG PRORAČUNA}

Postrojenje za prečišćavanje otpadnih voda u naselju Kovilj prikazano na Sl. 1 je izgrađeno iz dve etape tako da je druga etapa obuhvatala samo nadogradnju postojećeg postrojenja izgradnjom drugog SBR reaktora za 3250 stanovnika [4]. Kada je postrojenje pušteno $u$ rad upotrebljavao se samo SBR1 bazen, dok je SBR2 služio kao rezervni, u slučaju da dotekla voda premaši kapacitet SBR1 bazena.

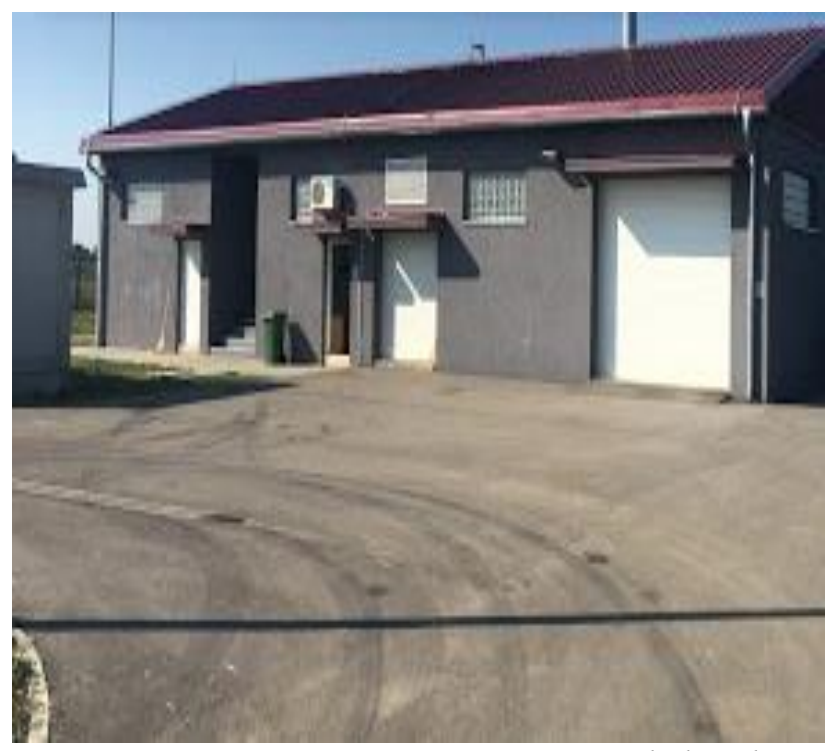

Slika 1. Postrojenje za prečišćavanje otpadnih voda $u$ naselju Kovilj

Hidraulički proračun koji je rađen prilikom dizajniranja procesa za prečišćavanje otpadnih voda je obuhvatao proračun količine ulazne netaložene sirove otpadne voda, organskog opterećenja sirove vode, zapremine SBR bazena, procesa denitrifikacije, procesa uklanjanja fosfora, procesa aeracije i potrebne doze koagulanta $u$ procesu prečišćavanja [3].

$\mathrm{Na}$ postrojenju se fosfor uklanja precipitacijom (taloženjem), dodavanjem koagulanta gvožđe(III)-hlorida $\left(\mathrm{FeCl}_{3}\right)$ u rastvorenom obliku [4], koji je efikasan za velike opsege $\mathrm{pH}$ i temperature, kojim se omogućava taloženje slabo taložive materije, pospešuje uklanjanje mutnoće i fosfora.
Prilikom izrade hidrauličkog proračuna bili su neophodni podaci o prosečnoj dnevnoj potrošnji vode po stanovniku i koeficijentima dnevne i časovne neravnomernosti koji se uzimaju na osnovu podataka o veličini naselja i broju stanovnika.

$\mathrm{U}$ radu nakon hidrauličkog proračuna su navedeni $\mathrm{i}$ opisani zakonom definisani i propisani opšti i tehnički uslovi koji se odnose na uslove za izvođenje radova, za objekte i opremu na izgradnji postrojenja za obradu otpadnih voda navedeni u radu se odnose na pripremnozavršne radove, izradu kanalizacionih šahtova i hidromašinsku opremu.

\section{ANALIZA OTPADNE VODE I GENERISANOG MULJA}

Postrojenje za prečišćavanje otpadnih voda u naselju Kovilj je projektovano tako da zadovolji potrebe koje će se javiti 15 do 20 godina nakon izgradnje, za kapacitet od 6500 stanovnika i pristiglu količinu vode po danu od 1290 $\mathrm{m}^{3} /$ dan. Merenje, upravljanje i kontrola efikasnosti uređaja na postrojenju tokom različitih faza procesa, omogućava pravilno rukovanje postrojenjem i obezbeđuje zahtevani kvalitet prečišćene vode.

Ceo proces prečišćavanja u SBR reaktoru obuhvata ukupno 9 faza [3]. Primenjuje se simultan proces nitrifikacije i denitrifikacije (SNdN) koji se sastoji iz 4 faze nitrifikacije i 3 faze denitrifikacije, nakon kojih slede faza taloženja i pražnjenja.

Ukupna dužina trajanja jednog ciklusa obrade vode iznosila je 6.1 h. Simultan proces nitrifikacije denitrifikacije u SBR reaktoru se odvija prema sledećem redosledu:

1. Nitrifikacija

2. Denitrifikacija

3. Nitrifikacija

4. Denitrifikacija

5. Nitrifikacija

6. Denitrifikacija

7. Nitrifikacija

8. Taloženje

9. Pražnjenje

Rezultati dobijeni analizama uzorkovane otpadne vode i mulja, kao i redovno praćenje kvalitet sirove otpadne vode služe za neposredno prilagođavanje procesa prečišćavanja u cilju postizanja što boljeg kvaliteta efluenta.

Uzorci za laboratorijske analize se uzimaju na ulazu, izlazu i u samim objektima postrojenja za obradu otpadnih voda nakon završenih faza procesa Ispitivanja sanitarne otpadne vode sa postrojenja obuhvata fizičkohemijske i mikrobiološke analize.

Usled kontinuiranog razvoja i ekspanzije industrije, sezonske aktivnosti poljoprivrede $\mathrm{u}$ analiziranom području stvaraju se velike razlike u količini i sastavu zagađujućih materija u otpadnoj vodi, i samim tim variraju vrednosti rezultata redovnih fizičko-hemijskih i 
mikrobioloških ispitivanja otpadne vode. Na Dijagramu 1. su upoređene vrednosti rezultata opterećenja HPK parametra za januar, februar i maj mesec 2018. dobijenih uzorkovanjem otpadne vode tokom istraživačkog rada za potrebe izrade Master rada.

Dijagaram 4. Pokazatelj razlika u opterećenju HPK parametra između zimskog i prolećnog perioda.

Navedene koncentracije su izražene u $\mathrm{mg} / \mathrm{l}$.

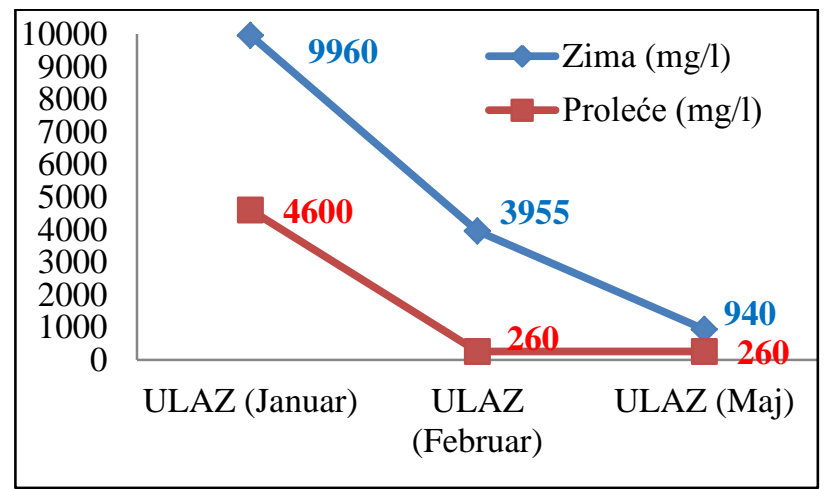

Visoki $\mathrm{BPK}_{5}$, HPK i SS se javljaju prilikom razgradnje koloidnih i suspendovanih materija tokom klanja stoke. Pesticidi, đubriva, navodnavanje prilikom kojeg se podzemne i površinske vode obogaćuju solima i nitratima, različite hemikalije i tečni stajnjak (sadrži velike količine natrijuma, kalijuma i fosfora sa stočnih farmi) troše $\mathrm{O}_{2}$, utiču na razvoj algi i izazivaju eutrofikaciju kada dospeju u vodotokove [2].

Iz priloženog se može zaključiti da je PPOV više opterećen u zimskom periodu, a da rezultati sa izlaza u mesecu maju, bez obzira na postignut zahtevani stepen prečišćavanja, ukazuju na efluent sa višim vrednostima pomenutih parametara.

\section{ZAKLJUČAK}

U okviru rada dat je detaljan prikaz izgradnje postrojenja po etapama, sa detaljnom tehnološkom šemom SBR reaktora. U radu je prikazana analiza osnovnih parametara kvaliteta obrađene otpadne vode u cilju utvrđivanja efikasnosti projektovanih tehnoloških operacija za redukciju kontaminacije otpadnog toka opštine Kovilj. Osnovna uloga projektovanog postrojenja je da se na njega dovedu i prečiste sve otpadne vode sa teritorije naselja Kovilj i njegove okoline.
$\mathrm{Na}$ osnovu kompletne anaIize rada sistema zaključilo se da izgrađeni objekti i instalirana oprema omogućavaju efikasan rad SBR procesa u svim uslovima eksploatacije. Redovnom kontrolom izlaznih koncentracija zakonom definisanih parametara potrebno je i moguće pratiti efikasnost rada kako čitavog sistema, tako i pojedinačnih tehnoloških operacija. Puštanje u rad postrojenja omogućilo je suštinsko unapređenje uslova životne sredine i razvoj infrastrukture u oblasti tretmana otpadnih tokova opštine Kovilj.

\section{LITERATURA}

[1] B. Dalmacija: "Monitoring otpadnih voda i njihov uticaj na životnu sredinu“, Novi Sad, 2016.

[2] Metcalf \& Eddy: "WASTEWATER ENGINEERING: Treatment and Resource Recovery“, Peto izd., Njujork, 2014.

[3] D. Krčmar: "Upravljanje otpadnim vodama u industriji“, Novi Sad, 2017.

[4] Arhiva Javnog komunalnog preduzeća Vodovod i kanalizacija: "Projektno rešenje SBR tretmana otpadne vode u Kovilju“, Novi Sad, 2018.

\section{Kratka biografija:}

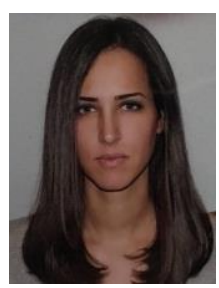

Asja Dorotka rođena je u Novom Sadu 1990. god. Master rad na Fakultetu tehničkih nauka iz oblasti Inženjerstva tretmana i zaštite voda - Analiza rada postrojenja za prečišćavanje otpadnih voda u naselju Kovilj odbranila je 2020.god.

kontakt: dorotka.asja@gmail.com

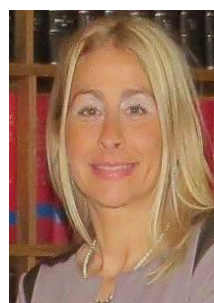

Maja Turk Sekulić rođena je 1976. godine u Novom Sadu. Gimnaziju Jovan Jovanović Zmaj završila je 1995. godine. Diplomirala na Tehnološkom fakultetu 2003. godine. Doktorirala 2009. godine na Fakultetu tehničkih nauka. Uža oblast interesovanja-Zelene tehnologije tretmana u domenu inženjerstva zaštite životne sredine.

kontakt: majaturk@uns.ac.rs 